\title{
A short stereoselective synthesis of (+)-(6R,2'S)- cryptocaryalactone via ring-closing metathesis
}

\author{
Palakodety Radha Krishna ${ }^{*}{ }^{1}$, Krishnarao Lopinti ${ }^{1}$ and K. L. N. Reddy ${ }^{2}$
}

\section{Full Research Paper}

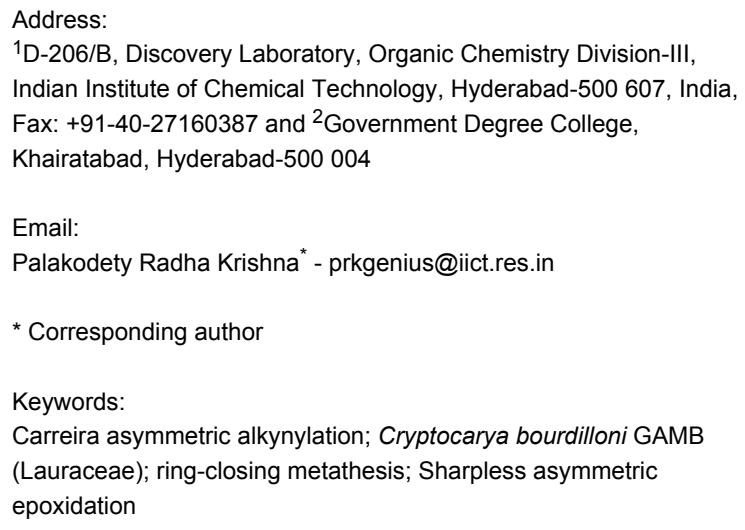

Beilstein Journal of Organic Chemistry 2009, 5, No. 14 doi:10.3762/bjoc.5.14

Received: 27 February 2009

Accepted: 03 April 2009

Published: 24 April 2009

Associate Editor: I. Marek

(C) 2009 Radha Krishna et al; licensee Beilstein-Institut. License and terms: see end of document.

\begin{abstract}
A short stereoselective synthesis of (+)-(6R,2'S)-cryptocaryalactone was successfully completed. Key steps included the application of Carreira's asymmetric alkynylation reaction to form a propargylic alcohol and subsequently lactone formation using the powerful ring-closing metathesis reaction.
\end{abstract}

\section{Introduction}

Natural products play an important role in the development of drugs and mankind has always taken advantage of nature as pharmacy: approximately $40 \%$ of the drugs that have been approved over the last years are either natural products or derivatives and analogs thereof [1-3]. Indeed, 5,6-dihydropyran-2ones of both natural and non-natural origin have been found to be cytotoxic. In addition to many other relevant pharmacological properties [4-7], they inhibit HIV protease [8,9], induce apoptosis [10-15], and have even proved to be antileukemic [16]. At least some of these pharmacological effects may be related to the presence of the conjugated double bond, which acts as a Michael acceptor [17-23].
One of the sub-classes of these 5,6-dihydro- $2 H$-pyran-2-one compounds is the styryl lactones which possess a styryl moiety side chain. The styryl moiety of goniothalamin has been shown to be of importance for its cytotoxic effect on different cancer cells as well as its antimicrobial, larvicidal activity and antiinflammatory activity [24]. The styryl-pyrone skeleton is often found in natural products from Equisetaceae and also from the primitive angiosperm families, such as Lauraceae, Piperaceae, Ranunculaceae and Zingiberaceae.

Cryptocaryalactone 1 [25,26], kurzilactone (2) [27], goniothalamin (3) [28], (+)-obolactone (4) [29] and (+)-cryptofoline 
<smiles>CC(=O)OC(/C=C/c1ccccc1)CC1CC=CC(=O)O1</smiles>

(+)-(6R,2' S)-Cryptocaryalactone (1)<smiles>O=C(/C=C/c1ccccc1)C[C@@H](O)C[C@@H]1CC=CC(=O)O1</smiles>

Kurzilactone (2)<smiles>O=C1C=CC[C@@H](/C=C/c2ccccc2)O1</smiles><smiles>O=C1C=C(/C=C/c2ccccc2)O[C@@H](C[C@H]2CC=CC(=O)O2)C1</smiles>

(+)-Obolactone (4)<smiles>O=C1C=CC[C@@H](/C=C/C[C@H](O)C[C@H](O)/C=C/c2ccccc2)O1</smiles>

(+)-Cryptofoline (5)

Figure 1: Some natural products containing styryl lactones.

(5) [30] (Figure 1) are some of the naturally occurring styryl lactones. $(+)-\left(6 R, 2^{\prime} S\right)$-Cryptocaryalactone (1) first featured in the phytochemical literature when its isolation from Cryptocarya bourdilloni GAMB (Lauraceae) was reported in 1972 by Govindachari $[31,32]$. Its absolute stereochemistry was established by H. H. Meyer through stereoselective synthesis [25] Recently Yadav et al. have synthesized $\left(6 R, 2^{\prime} S\right)$-cryptocaryalactone and its epimer using stereoselective reduction of $\delta$-hydroxy- $\beta$-keto ester [33]. All other possible isomers of cryptocaryalactone were also isolated from $C$. bourdilloni, $C$. moschata and C. myrtifolia and their absolute configuration was established [34]. These cryptocaryalactones are natural germination inhibitors with no effect on corn [35]. We were interested in synthesizing natural products containing 5,6-dihydro- $2 \mathrm{H}$ pyran-2-one moiety [36,37], and herein we describe a short and efficient synthesis of cryptocaryalactone $\mathbf{1}$.

\section{Results and Discussion}

\section{Retrosynthetic analysis}

Retrosynthetic analysis (Figure 2) reveals that compound $\mathbf{1}$ could be synthesized from bis-olefin 6 by a ring-closing metathesis reaction, while the bis-olefin itself could be realised from the acryloylation of the corresponding homoallylic alcohol which in turn can be synthesized from 7. Chiral propargyl alcohol 7 was obtained by the Carreira asymmetric alkynylation reaction of the corresponding aldehyde, which was synthesized from the corresponding primary alcohol that was obtained from a regioselective ring-opening reaction of 2,3-epoxy alcohol 8 .

The known 2,3-epoxy alcohol $\mathbf{8}$ was synthesized from the corresponding dienyl alcohol by the well-established Sharpless asymmetric epoxidation conditions in $>94 \%$ ee as described in<smiles>C=CC=CC[C@@H](C[C@@H](C=Cc1ccccc1)OC(C)=O)OC(=O)C=C</smiles>

Ring closing metathesis

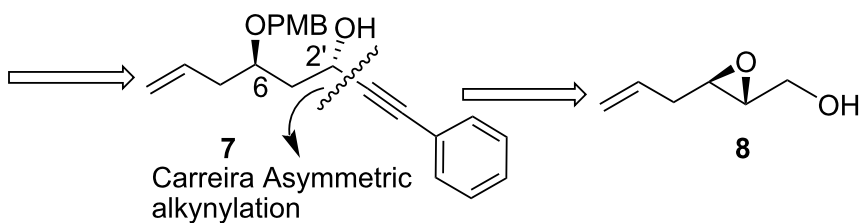

Figure 2: Retrosynthetic approach. 


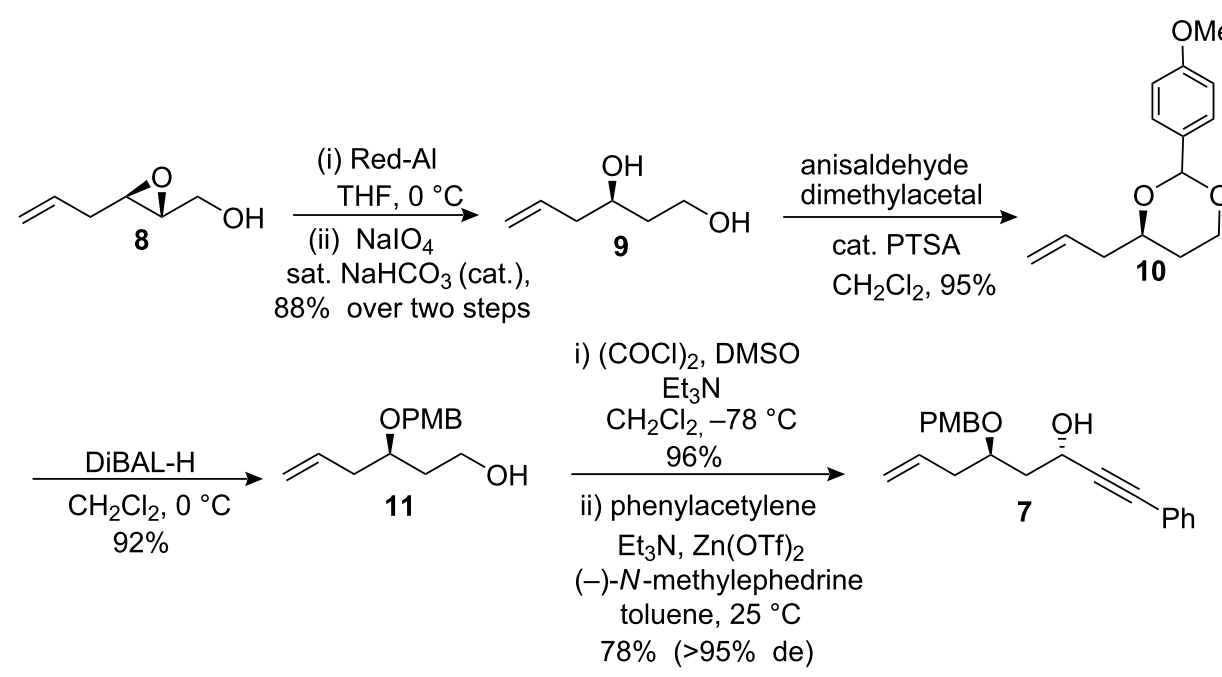

Scheme 1: Synthesis of chiral propargyl secondary hydroxyl group.

literature [38,39]. Compound $\mathbf{8}$ undergoes a reductive ringopening reaction with Red-Al under standard reaction conditions to furnish the 1,3-diol 9 in $88 \%$ yield. Traces of 1,2-diol were oxidatively cleaved with $\mathrm{NaIO}_{4}$ in presence of catalytic amount of saturated $\mathrm{NaHCO}_{3}$ solution. Diol 9 was protected with anisaldehyde dimethylacetal in presence of PTSA to afford compound $\mathbf{1 0}$ in $95 \%$ yield, which was regioselectively opened with DIBAL-H to afford the primary alcohol 11 in $92 \%$ yield (Scheme 1).

The primary alcohol $\mathbf{1 1}$ was oxidized under Swern conditions and the crude aldehyde was exposed to the alkynylation reaction directly. Several base-mediated alkynylation conditions were examined to access the requisite propargyl alcohol 7 (Table 1).

Amongst all of these, the Carreira asymmetric alkynylation gave excellent diastereomeric excess (>94\% de) $[40,41]$ and the propargyl alcohol 7 was obtained with the correct absolute configuration.

\begin{tabular}{|l|lll|}
\hline \multicolumn{4}{|l|}{ Table 1: Asymmetric alkynylation with phenylacetylene. } \\
\hline Reagents & Solvent & Temperature & $\mathrm{de}^{\mathrm{a}}$ \\
\hline$n$-BuLi & THF & $-78{ }^{\circ} \mathrm{C}$ & $28 \%$ \\
LDA & THF & $-78{ }^{\circ} \mathrm{C}$ & $56 \%$ \\
LDA/HMPA & THF & $-78{ }^{\circ} \mathrm{C}$ & $78 \%$ \\
Zn $(\mathrm{OTf})_{2}, \mathrm{Et}_{3} \mathrm{~N}$, & toluene & $25^{\circ} \mathrm{C}$ & $94 \%$ \\
$(-)-N$-methylephedrine & & & \\
\hline
\end{tabular}

${ }^{\text {aT }}$ The diastereoselectivity was determined by NMR studies.

\section{Confirmation of absolute configuration}

The structure of compound 7 was confirmed by ${ }^{1} \mathrm{H}$ NMR and ${ }^{13} \mathrm{C}$ spectral analysis (Scheme 2 ). The absolute stereochemistry was assigned based on Rychnovsky's analogy [42-44].

According to literature precedent, the relative configuration of a secondary 1,3-diol can be assigned from the chemical shift of acetonide carbon atoms in ${ }^{13} \mathrm{C}$ NMR spectrum. So, upon deprotection of 7, diol 12 was obtained in good chemical yield (84\%) and was further protected with 2,2-DMP, in presence of catalytic amount of PTSA, to furnish compound 13. The analytical data of acetonide $\mathbf{1 3}$ confirmed the anti configuration of the 1,3diol. Since the first hydroxyl center was obtained through an unambiguous method, the stereochemistry of the newly created hydroxyl functionality could be confirmed as that depicted in Scheme 2.

The propargylic alcohol 7 was chemoselectively reduced with $\mathrm{LiAlH}_{4}$ in THF at $0{ }^{\circ} \mathrm{C}$ to give cinnamyl alcohol derivative $\mathbf{1 4}$ (87\%, Scheme 3). Alcohol 14 was protected as its acetate under conventional reaction conditions. The PMB ( $p$-methoxybenzyl protecting group) in compound $\mathbf{1 5}$ was selectively removed with DDQ in $\mathrm{CH}_{2} \mathrm{Cl}_{2} / \mathrm{H}_{2} \mathrm{O}(19: 1)$ to afford homoallylic alcohol $16(89 \%)$ without promoting the migration of the acetyl group. Finally, 16 was acrylated with acryloyl chloride/ $\mathrm{Et}_{3} \mathrm{~N} / \mathrm{CH}_{2} \mathrm{Cl}_{2} / 0$ ${ }^{\circ} \mathrm{C}$ to furnish the required bis-olefin 6 in $82 \%$ yield. Ringclosing metathesis of bis-olefin 6 with Grubbs' $1^{\text {st }}$ generation catalyst (I; $10 \mathrm{~mol} \%)$ [45] gave the required $(+)-\left(6 R, 2^{\prime} S\right)$ cryptocaryalactone (1) as a solid in 58\% yield \{m.p. 122-125 ${ }^{\circ} \mathrm{C} /$ lit. $126-127{ }^{\circ} \mathrm{C}$ and $[\alpha]_{\mathrm{D}}=+20.1(c=0.20) /$ lit. $+19.0(c=$ $0.67)\}[25]$. All the spectral data matched with the literature values. 


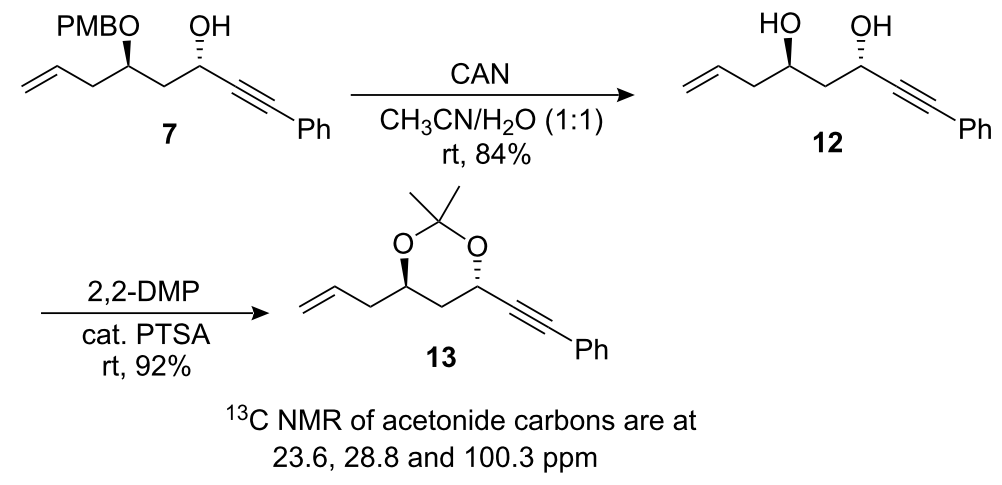

Scheme 2: Determination of the stereochemistry of the 1,3-anti diols.
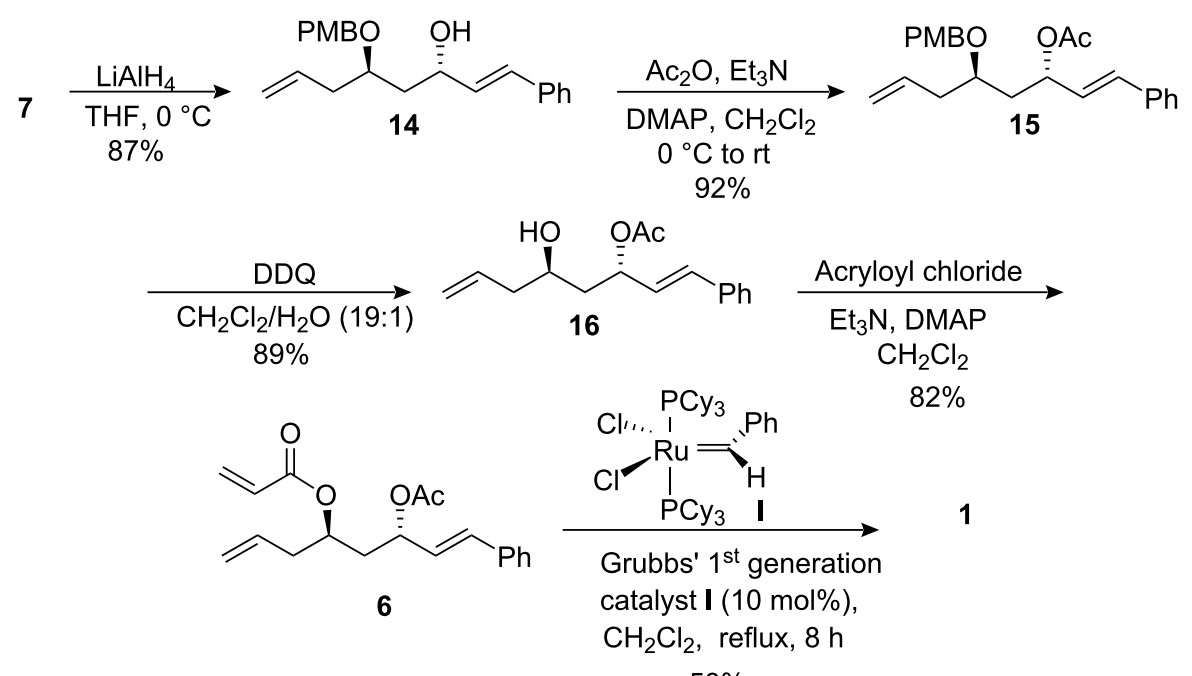

$58 \%$

Scheme 3: Synthesis of cryptocaryalactone by RCM.

\section{Conclusion}

In conclusion, a short stereoselective total synthesis of $\mathbf{1}$ has been accomplished by a convergent strategy wherein a chiral 2,3-epoxy alcohol was the starting material and Sharpless asymmetric epoxidation and Carreira asymmetric alkynylation were used as key steps for generating unambiguous assigned stereocenters. More importantly, the Grubbs' ring-closing metathesis protocol was applied to construct the final 5,6-dihydropyrone ring of cryptocaryalactone. The advantage of this synthetic methodology is that one can in principle synthesize the other three diastereomers of cryptocaryalactone by altering the Sharpless epoxidation and Carreira's conditions.

\section{Supporting Information}

\section{Supporting Information File 1}

Experimental Data

[http://beilstein-journals.org/bjoc/content/supplementary/

1860-5397-5-14-S1.doc]

\section{Acknowledgments}

One of the authors (K.L.) thanks the CSIR, New Delhi, for financial support in the form of a fellowship. 


\section{References}

1. Lee, K.-H. J. Nat. Prod. 2004, 67, 273-283. doi:10.1021/np030373o

2. Butler, M. S. J. Nat. Prod. 2004, 67, 2141-2153. doi:10.1021/np040106y

3. Clardy, J.; Walsh, C. Nature 2004, 432, 829-837. doi:10.1038/nature03194

4. Larsen, A. K.; Escargueil, A. E.; Skladanowski, A. Pharmacol. Ther. 2003, 99, 167-181. doi:10.1016/S0163-7258(03)00058-5

5. Richetti, A.; Cavallaro, A.; Ainis, T.; Fimiani, V. Immunopharmacol. Immunotoxicol. 2003, 25, 441-449. doi:10.1081//PH-120024511

6. Koizumi, F.; Ishiguro, H.; Ando, K.; Kondo, H.; Yoshida, M.; Matsuda, Y.; Nakanishi, S. J. Antibiot. 2003, 56, 603-609.

7. Köster, M.; Lykke-Andersen, S.; Elnakady, Y. A.; Gerth, K.; Washausen, P.; Höfle, G.; Sasse, F.; Kjems, J.; Hauser, H. Exp. Cell Res. 2003, 286, 321-331. doi:10.1016/S0014-4827(03)00100-9

8. Chrusciel, R. A.; Strohbach, J. W. Curr. Top. Med. Chem. 2004, 4, 1097-1114.

9. Agrawal, V. K.; Singh, J.; Mishra, K. C.; Khadikar, P. V.; Jaliwala, Y. A. ARKIVOC 2006, No. ii, 162-177.

10. Inayat-Hussain, S. H.; Annuar, B. O.; Din, L. B.; Taniguchi, N. Toxicol. Lett. 2002, 131, 153-159. doi:10.1016/S0378-4274(02)00025-5

11. Inayat-Hussain, S. H.; Annuar, B. O.; Din, L. B.; Ali, A. M.; Ross, D. Toxicol. in Vitro 2003, 17, 433-439. doi:10.1016/S0887-2333(03)00051-1

12. Chan, K. M.; Rajab, N. F.; Ishak, M. H. A.; Ali, A. M.; Yusoff, K.; Din, L. B.; Inayat-Hussain, S. H. Chem.-Biol. Interact. 2006, 159, 129-135 doi:10.1016/j.cbi.2005.10.107

13. Blatt, N. B.; Glick, G. D. Bioorg. Med. Chem. 2001, 9, 1371-1384. doi:10.1016/S0968-0896(01)00041-4

14. Huang, Z. Chem. Biol. 2002, 9, 1059-1072. doi:10.1016/S1074-5521(02)00247-8

15. Newmeyer, D. D.; Ferguson-Miller, S. Cell 2003, 112, 481-490. doi:10.1016/S0092-8674(03)00116-8

16. Kikuchi, H.; Sasaki, K.; Sekiya, J.; Maeda, Y.; Amagai, A.; Kubohara, Y.; Oshima, Y. Bioorg. Med. Chem. 2004, 12, 3203-3214. doi:10.1016/j.bmc.2004.04.001

17. Hoffmann, H. M. R.; Rabe, J. Angew. Chem., Int. Ed. Engl. 1985, 24, 94-110. doi:10.1002/anie.198500941

18. Negishi, E.-i.; Kotora, M. Tetrahedron 1997, 53, 6707-6738. doi:10.1016/S0040-4020(97)00199-3

19. Collins, I. J. Chem. Soc., Perkin Trans. 11999, 1377-1395. doi:10.1039/a808137i

20. Carter, N. B.; Nadany, A. E.; Sweeney, J. B. J. Chem. Soc., Perkin Trans. 1 2002, 2324-2342. doi:10.1039/b007664n

21. Bialy, L.; Waldmann, H. Chem.-Eur. J. 2004, 10, 2759-2780. doi:10.1002/chem.200305543

22. Njardarson, J. T.; Gaul, C.; Shan, D.; Huang, X.-Y.; Danishefsky, S. J. J. Am. Chem. Soc. 2004, 126, 1038-1040. doi:10.1021/ja039714a

23. Shaw, S. J.; Sundermann, K. F.; Burlingame, M. A.; Myles, D. C.; Freeze, B. S.; Xian, M.; Brouard, I.; Smith, A. B., III. J. Am. Chem. Soc. 2005, 127, 6532-6533. doi:10.1021/ja051185i
24. de Fátima, A.; Marquissolo, C.; de Albuquerque, S.; Carraro-Abrahão, A. A.; Pilli, R. A. Eur. J. Med. Chem. 2006, 41, 1210-1213. doi:10.1016/j.ejmech.2006.05.010

25. Meyer, H. H. Liebigs Ann. Chem. 1984, 977-981. doi:10.1002/jlac.198419840515

26. Mori, Y.; Furukawa, H. Chem. Pharm. Bull. 1994, 42, 2161-2163.

27. Fu, X.; Sévenet, T.; Hamid, A.; Hadi, A.; Remy, F.; Païs, M. Phytochemistry 1993, 33, 1272-1274. doi:10.1016/0031-9422(93)85065-Y

28. Blázquez, M. A.; Bermejo, A.; Zafra-Polo, M. C.; Cortes, D. Phytochem. Anal. 1999, 10, 161-170. doi:10.1002/(SICI)1099-1565(199907/08)10:4<161::AID-PCA453>3.0. CO;2-2

29. Matsuoka, Y.; Aikawa, K.; Irie, R.; Katsuki, T. Heterocycles 2005, 66, 187-194. doi:10.3987/COM-05-S(K)73

30. Zhang, J.; Li, Y.; Wang, W.; She, X.; Pan, X. J. Org. Chem. 2006, 71, 2918-2921. doi:10.1021/jo060028e

31. Govindachari, T. R.; Parthasarathy, P. C.; Modi, J. D. Indian J. Chem. 1972, 10, 149-151.

32. Govindachari, T. R.; Parthasarathy, P. C. Tetrahedron Lett. 1971, 3401-3402. doi:10.1016/S0040-4039(01)97189-8

33. Sabitha, G.; Bhaskar, V.; Reddy, S. S. S.; Yadav, J. S Tetrahedron 2008, 64, 10207-10213. doi:10.1016/j.tet.2008.08.032

34. Spencer, G. F.; England, R. E.; Wolf, R. B. Phytochemistry 1984, 23, 2499-2500. doi:10.1016/S0031-9422(00)84083-2

35. Drewes, S. E.; Horn, M. M.; Ramesar, N. S.; Ferreira, D.; Nel, R. J. J.; Hutchings, A. Phytochemistry 1998, 49, 1683-1687. doi:10.1016/S0031-9422(98)00328-8

36. Radha Krishna, P.; Srinivas, R. Tetrahedron Lett. 2007, 48, 2013-2015. doi:10.1016/j.tetlet.2007.01.056

37. Radha Krishna, P.; Ramana Reddy, V. V. Tetrahedron Lett. 2005, 46, 3905-3907. doi:10.1016/j.tetlet.2005.03.202

38. Katsuki, T.; Martin, V. S. Asymmetric Epoxidation of Allylic Alcohols: The Katsuki-Sharpless Epoxidation Reaction. In Organic Reactions; Paquette, L. A., Ed.; John Wiley \& Sons Inc.: New York, 1996; Vol. 48, pp 1-299.

39. Ma, S.; Ni, B. Chem.-Eur. J. 2004, 10, 3286-3300. doi:10.1002/chem.200305581

40. García-Fortanet, J.; Murga, J.; Carda, M.; Marco, J. A. Tetrahedron 2004, 60, 12261-12267. doi:10.1016/j.tet.2004.10.010

41. Frantz, D. E.; Fässler, R.; Carreira, E. M. J. Am. Chem. Soc. 2000, 122, 1806-1807. doi:10.1021/ja993838z

42. Rychnovsky, S. D.; Skalitzky, D. J. Tetrahedron Lett. 1990, 31, 945-948. doi:10.1016/S0040-4039(00)94399-5

43. Rychnovsky, S. D.; Rogers, B.; Yang, G. J. Org. Chem. 1993, 58, 3511-3515. doi:10.1021/jo00065a011

44. Evans, D. A.; Hoveyda, A. H. J. Am. Chem. Soc. 1990, 112, 6447-6449. doi:10.1021/ja00173a071 45. Deiters, A.; Martin, S. F. Chem. Rev. 2004, 104, 2199-2238. doi:10.1021/cr0200872 


\section{License and Terms}

This is an Open Access article under the terms of the Creative Commons Attribution License

(http://creativecommons.org/licenses/by/2.0), which permits unrestricted use, distribution, and reproduction in any medium, provided the original work is properly cited.

The license is subject to the Beilstein Journal of Organic Chemistry terms and conditions:

(http://www.beilstein-journals.org/bjoc)

The definitive version of this article is the electronic one which can be found at:

doi:10.3762/bjoc.5.14 